$\begin{array}{ll} & \text { Etnográfica } \\ \text { etnográfica } & \text { Revista do Centro em Rede de Investigação em }\end{array}$

Antropologia

vol. 11 (2) | 2007

Vol. 11 (2)

\title{
Chiara Pussetti, Poetica delle Emozioni: I Bijagó della Guinea Bissau
}

\section{Luís Silva Pereira}

\section{(2) OpenEdition \\ Journals}

\section{Edição electrónica}

URL: https://journals.openedition.org/etnografica/2058

DOI: 10.4000/etnografica.2058

ISSN: 2182-2891

\section{Editora}

Centro em Rede de Investigação em Antropologia

\section{Edição impressa}

Data de publição: 1 novembro 2007

Paginação: 489-491

ISBN: 0873-6561; E-ISBN 2182-2891

ISSN: 0873-6561

\section{Refêrencia eletrónica}

Luís Silva Pereira, «Chiara Pussetti, Poetica delle Emozioni: I Bijagó della Guinea Bissau», Etnográfica [Online], vol. 11 (2) | 2007, posto online no dia 27 setembro 2012, consultado o 12 fevereiro 2022. URL: http://journals.openedition.org/etnografica/2058 ; DOI: https://doi.org/10.4000/etnografica.2058

Este documento foi criado de forma automática no dia 12 fevereiro 2022.

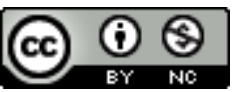

Etnográfica is licensed under a Creative Commons Attribution-NonCommercial 4.0 International License. 


\title{
Chiara Pussetti, Poetica delle Emozioni: I Bijagó della Guinea Bissau
}

\author{
Luís Silva Pereira
}

\section{REFERÊNCIA}

Chiara Pussetti, Poetica delle Emozioni: I Bijagó della Guinea Bissau, Bari, Editori Laterza, 2005, 275 páginas.

1 Este livro de Chiara Pussetti nasce do trabalho de campo que constituiu a base empírica da sua tese de doutoramento em antropologia cultural e etnologia, pela Universidade de Turim.

2 Esse trabalho decorreu em Bubaque, a ilha principal do arquipélago de Bijagós, pertencente à Guiné-Bissau e formado por um conjunto de oitenta e oito ilhas, que se distinguem entre si por assinaláveis diferenças linguísticas e socioculturais. A autora desenvolveu as suas pesquisas entre 1994 e 2001, em períodos de permanência de duração diversa, perfazendo um total de dezasseis meses. A população do arquipélago é de quinze a vinte mil pessoas e a de Bubaque é de cerca de duas mil pessoas. A pesquisa desenvolveu-se exclusivamente entre os Iagbaaga, “os habitantes de Bubaque", sobretudo na aldeia de Bijante. Com mais de quinhentos habitantes, e contando entre eles os elementos de maior autoridade ritual da ilha, esta aldeia é considerada por muitos, segundo a autora, como aquela que melhor preservou os traços da organização social tradicional, a que mais resiste à mudança.

3 No início da sua pesquisa, a autora foi seduzida por um ritual específico (manras iarebok), de possessão feminina, mas as observações e reflexões posteriores deslocaram o foco da sua atenção para alguns dos temas recorrentes do quotidiano Iagbaaga: "a responsabilidade no confronto com os outros, o respeito pelos anciãos, os ciúmes e as invejas entre parentes, as lágrimas das mulheres, as paixões confusas dos jovens, a necessidade de dominar-se" (p. 13; esta e as seguintes traduções são minhas). 
4 Pussetti entregou-se a um longo e desejado processo de impregnação da experiência vivencial dos Iagbaaga e foi categorizada pelos habitantes de Bubaque como uma criança, porque, tal como uma criança, ainda tinha de aprender, nada tinha na cabeça, não ouvia/não entendia (v. pp. 58, 65-69), ainda não pertencia - de corpo inteiro e de pleno direito, com a responsabilidade (v. p. 84) que dá o saber - ao mundo Iagbaaga.

5 A autora assume-se, então, como aprendiz desse universo e procura entender como se expressam as emoções em Bubaque, como são designadas e avaliadas pelos que as sentem e as nomeiam, que papéis desempenham essas emoções no quotidiano dos habitantes da aldeia de Bijante e que códigos morais são manifestados através delas.

Pussetti começa por chamar a atenção para a dificuldade de sabermos do que falamos quando falamos de "emoções", reconhecendo a concorrência de factores biológicos e culturais na sua formação e expressão. $\mathrm{Na}$ investigação que desenvolve, recolhe e reflecte sobre as apreciações dos habitantes da ilha de Bubaque a propósito de práticas próprias e alheias, indaga sobre "emoções íntimas e estados mentais, reflexões e diferentes concepções relativas a esses estados, em relação com o contexto cultural e como forma de discurso social" (p. 15), analisa "algumas configurações emocionais que, segundo a estética local, constituem a tonalidade afectiva e a forma retórica privilegiada para a narrativa do eu" (idem) e toma conhecimento de como as emoções são manipuladas com fins estratégicos.

7 Para os Bijagós em geral, as emoções, tal como as doenças, podem passar de uma pessoa a outra, circulando e contagiando especialmente as que mantêm entre si uma relação próxima. Esse processo é independente das vontades dos envolvidos, acontece no decorrer da vida quotidiana e de modo tão mais intenso quanto maior for o conflito ou a crise.

8 No contacto com os nativos da aldeia de Bijante, a autora iniciou o seu trabalho fazendo emergir as diferentes concepções de emoções das pessoas em presença, incluídas as suas. Os resultados dessa iniciativa empurraram-na para mais longe das teorias que encaravam as emoções como essências universais, inatas, pré-culturais (v. p. 25), e, para demonstrar a indispensabilidade da sociedade humana na formação e desenvolvimento do mundo emocional dos indivíduos, a autora recorre a estudos de neurocientistas, psiquiatras e antropólogos, situa-se no campo da antropologia das emoções (os autores de referência são: Michele Rosaldo, Toward an Anthropology of Self and Feeling, 1984; Lila Abu-Lughod, Veiled Sentiments, 1986; e Catherine Lutz, Unnatural Emotions, 1988) e cruza a teoria antropológica com a sua experiência de terreno entre os Bijagós. Assim, traça um percurso entre autores e escolas desde quando as emoções eram consideradas como parte de um mundo privado, psicológico, inefável, inato e independente da cultura (v. pp. 48 e 49), até à actualidade, recorrendo nomeadamente às teorias construtivistas, e considera, sustentando-se nas observações que faz entre os Iagbaaga, que o discurso (entendido no sentido que lhe atribui Foucault, em La Volonté de Savoir, 1976, e L'Usage des Plaisirs, 1984) sobre as emoções envolve "poder, política, parentela, transformações históricas, diferenças de género, conceitos de normalidade e desvio" (p. 51).

9 A investigação é intensiva e centrada, maioritariamente, no universo feminino. 0 mundo masculino, até pelas próprias características da sociedade estudada, não se revela facilmente aos olhos da autora. $O$ volume de informação recolhida e a qualidade da reflexão produzida são notáveis, no entanto, refere-se essencialmente ao mundo das mulheres. O quarto capítulo, parcialmente dedicado ao estudo da bruxaria e da 
feitiçaria, é aquele que lança um pouco mais de luz sobre o quotidiano dos homens de Bubaque.

Pussetti recorre às reflexões das mulheres Iagbaaga sobre as suas experiências de vida, centra a sua atenção nas apreciações que elas fazem sobre modelos de conduta, valores a preservar, perigos a evitar, conflitos entre pessoas e emoções, e procura identificar como esse modo de pensar contribui para dar um sentido à existência dessas mesmas pessoas. Lembrando a gravura de Escher, na qual duas mãos se desenham mutuamente, as emoções surgem, na obra de Chiara Pussetti, como modelos construídos pelos humanos que por sua vez os constroem a eles mesmos.

11 Ao longo dos capítulos do livro são analisados sentimentos, alguns deles perigosos devido à sua intensidade e impetuosidade, bem como a forma como devem ser expressos para minorar os seus efeitos nefastos. No trabalho exaustivo que levou a cabo com as mulheres de Bijante, Pussetti esclareceu os papéis a desempenhar pelas mulheres no mundo emocional Iagbaaga, nomeadamente através da relação que mantêm com a morte e da função libertadora dos cantos que entoam. Para além dos cantos fúnebres existem outros três tipos de canto, que funcionam como contraponto às rígidas normas dos anciãos relativas ao controlo das emoções e à responsabilidade do indivíduo Iagbaaga. Através da análise do conteúdo desses cantos, a autora identifica como as normas determinadas pelos anciãos são subvertidas pela prática quotidiana e como os excessos, a falta de controlo das emoções, das paixões dilacerantes, são assumidas (e, em alguns casos, purgadas) através dos cantos, os quais "representam um modo de ser alternativo e encorajam, reflectindo-o, um lado da experiência mais tolerante, mais "humano"' (p. 223).

O objectivo mais ambicioso e mais interessante de Poetica delle Emozioni é o de utilizar as conclusões da pesquisa de Bubaque para fazer emergir aspectos relevantes da nossa sociedade, superando a tendência para a naturalização, a reificação e as múltiplas convenções construídas a propósito das emoções, procurando, desse modo, revelar a natureza política e social que as caracteriza (v. p. 231). Esta obra constitui um excelente contributo para uma reflexão crítica que torne os indivíduos mais conscientes do modo como nas emoções se conjugam "percepções, sensações, avaliações, aprendizagem, orientações cognitivas, moralidade pública e ideologia cultural” (p. 232).

\section{AUTORES}

\section{LUÍS SILVA PEREIRA}

Instituto Superior de Psicologia Aplicada 